\title{
Behavioural Changes in Free-ranging Red Foxes (Vulpes vulpes) due to Sarcoptic Mange
}

Sarcoptic mange (Sarcoptes scabiei var. vulpes) reached Scandinavia in the mid-1970's and is mainly prevalent among red foxes (Vulpes vulpes) (Borg 1987). In the laboratory, foxes succumb 2-4 months after being infested, and it is commonly thought that carriers in the wild exhibit an abnormal behaviour and quickly die (Mörner \& Christensson 1984, Holt \& Berg 1990). However, there is a lack of comparative data from free-ranging animals to contribute to the ecology of the species in general and to supplement the content of the above selected references in particular (e.g. Plowright 1988). Using telemetry studies, I have compared the behaviour in winter of 2 mange infested and 2 healthy red foxes. The work took place in 1987 and 1990 in a boreal area adjacent to farmland in central Norway $\left(63^{\circ} 20^{\prime} \mathrm{N} 10^{\circ} 45^{\prime} \mathrm{E}\right)$.

During February and March 1987, I radiotracked a male and a female red fox, both mange infested, and in February and March 1990, 2 healthy females were radio-tracked in the same area. The individuals were tracked once daily and were randomly monitored for periods of up to $8 \mathrm{~h}$ (Kenward 1987). The activity pattern of each animal was tested with respect to night and day, with the expectancy that normal individuals would not diverge from a regular activity pattern, i.e. active at night and resting in daytime (Table 1). Active fixes are interpreted as hunting (e.g. by direct observations) and inactive fixes are interpreted as resting (e.g. by direct observations). As expected, an individual chi-square ${ }_{(2 \times 2)}$ table-test indicate that healthy red foxes more than the mangy red foxes are regularly nocturnal. Symptoms of scab on the skin (Todd et al. 1981) and clinical diagnosis with the assistance of a veterinary surgeon were used to verify mange infestation.

Significance $(\mathrm{p}<0.001)$ and close to significance $(p<0.10)$ were recorded for the 2 healthy individuals on the basis of regular roaming at night and resting during the day. In comparison, the mangy individuals demonstrated no significant values, but seemed to have more irregular rhytms of inactive versus active behaviour (Table 1). Furthermore, the mangy individuals lived in very small areas compared to healthy foxes and hence walked short distances (except in 1 instance), and operated in habitats not considered normal for foxes; when captured for tagging, the infested female had a scab about $2 \mathrm{~cm}$ in diameter at the base of her tail. The first 7 days after her release she showed regular nocturnal activity, mostly inside a $1 \mathrm{~km}^{2}$ area. However, she was inactive for the following 13 days except the last 1 when, in the middle of the day, she walked $6 \mathrm{~km}$ away from what until then had been the area she lived in, and was shot close to human settlement. The vixen seemed lethargic, her tail was hairless and her back had 
Table 1. Number of active and inactive telemetry fixes during day (07.00-19.00) and night (19.00-07.00) respectively of 2 mangy and 2 healthy red foxes monitored during late winter.

\begin{tabular}{|c|c|c|c|c|c|c|c|}
\hline \multirow{2}{*}{ Fox: } & \multirow{2}{*}{$\begin{array}{c}\text { Date } \\
\text { monitored } \\
\text { day, month }\end{array}$} & \multicolumn{2}{|c|}{ Fixes: Day } & \multicolumn{2}{|c|}{ Fixes: Night } & \multirow[b]{2}{*}{$\chi^{2}$} & \multirow[b]{2}{*}{$\mathrm{p}$} \\
\hline & & Active & Inactive & Active & Inactive & & \\
\hline$* 1$ & $22.02-13.03 .1987$ & 5 & 5 & 14 & 8 & 0.115 & 0.50 \\
\hline$* 2$ & $23.03-03.04 .1987$ & 0 & 3 & 7 & 5 & - & - \\
\hline 3 & $15.02-15.03 .1990$ & 5 & 13 & 34 & 2 & 23.37 & 0.001 \\
\hline 4 & $15.02-15.03 .1990$ & 10 & 8 & 38 & 11 & 3.14 & 0.10 \\
\hline
\end{tabular}

* Mangy fox.

a 7-8 $\mathrm{cm}$ diameter scab. The infested male had scabs on a large area of his back. For the first week following his release he remained active inside a $1 \mathrm{~km}^{2}$ area. He gradually spent more time resting in a nearby den, and died there around 3 April. The 2 healthy foxes showed regular nocturnal activity, leaving their daybed between dusk and dawn, and visiting most of their home ranges of $3.5 \mathrm{~km}^{2}$ and $9.5 \mathrm{~km}^{2}$, respectively.

Red foxes are mainly nocturnal, following a 24h rhythm (Ables 1975, Artois 1985). This was shown by the 2 healthy foxes in this study, but not the 2 infested ones which were inactive for periods of several days. Furthermore, the area use of the 2 healthy foxes was within the values reported for red foxes elsewhere in Scandinavia (Lindström 1982), whereas the mangy individuals operated within very limited areas, which is not considered normal under Nordic conditions. I suggest that the reason for the irregular rhythm and reduced activity in the 2 infested individuals is reduced fitness as a result of mange. Long rest periods may also accelerate other possible consequences of the disease, e.g. starvation and reduced vigilance. The latter was observed during the unexpected and hazardous daytime roaming of the infested female out of the area she had inhabited, leading to her death by shooting.
Under normal conditions, foxes require good cover, e.g. old forest (Burrows 1968, Weber $1985)$, this being practised by the 2 healthy foxes in this study, but not, according to my observations, by the mangy female which at the end of her life roamed around in daytime on open fields close to human settlement. This impression of atypical behaviour in mangeinfested foxes was strengthened by random sampling of 7 foxes in the study area, all of which had mange and were shot during the day near farms.

It has been reported that red foxes can recover from mange (Storm et al. 1976), but a marked reduction in the Scandinavian red fox population during the late 1970s and 1980s indicates that the disease significantly reduces the red fox population (Lindström et al. 1994). Furthermore mange has been reported in protected species like the mountain fox (Alopex lagopus) and lynx (Lynx lynx), the red fox being thought to be the vector (Bjärvall \& Lindström 1984). In Denmark, severe anxiety as to whether the red fox population will recover after mange has led to a vaccination programme for foxes (Steinar 1993). Because of the drastic consequences the disease may have for the red fox itself, and possibly also for species it interacts with, it may be worth increasing research into the relationships to obtain more knowledge and enable active 
management if this is deemed desirable. One contribution could be to study aspects of basic biology in individual, healthy and infested free-living animals.

Despite some weaknesses, e.g. few animals and tracking in different years, the results of this study support the assumptions of Mörner \& Christensson (1984) that infested foxes experience particular difficulties in finding food, in this case during long rest periods within limited areas lacking access to food. As Holt \& Berg (1990) supposed, it also seems that infested individuals may deviate from a normal nocturnal life in dense habitats - resulting in daytime exposure near humans.

\section{Acknowledgements}

I thank the veterinary surgeon, M. Fjølstad, for helping to diagnose mange and for valuable discussions on the topic, and E. Røskaft and 2 anonymous referees for valuable comments on the manuscript. The Environmental Division of the County Office in South Trøndelag County and the Schøyen Trust at the University of Trondheim - Norway provided financial support.

\section{Kristian Overskaug}

Norwegian Institute for Nature Research (Tunasletta, 7005) Trondheim, Norway.

\section{References}

Ables ED: Ecology of the red fox in America. The wild canids; their systematics, behavioral ecology and evolution. Van Nostrand Reinhold Co., New York, N.Y. 1975, 216-236.

Artois M: Use of space and time in the red fox (Vulpes vulpes) and the wild cat (Felis silvestris) in Lorraine. Gibier Faune Sauvage. 1985, 33-57.

Bjärvall A, Lindström D: Lodjuret 1974-83 i Norrbottens fjällvärld. Fauna och flora, 1984, 79, 213226.
Borg K: A review of wildlife diseases from Scandinavia. Journal of Wildlife Diseases. 1987, 23, 527533.

Burrows R: Wild Fox. Newton Abbot, Devon. 1968, $203 \mathrm{pp}$.

Holt $G$, Berg $C$ : Sarcoptesskabb hos rødrev og andre viltlevende rovdyr i Norge (Sarcoptic mange in red fox and other wild carnivores in Norway). Norsk Veterinærtidsskrift. 1990, 102, 427-432.

Kenward R: Wildlife Radio Tagging. Equipment, Field Techniques and Data Analysis. Biological Techniques series. 1987, 203 pp.

Lindström E: Population ecology of the Red Fox (Vulpes vulpes L.) in relation to food supply. Ph.D. Thesis, Univ. of Stockholm Sweden. 1982, $150 \mathrm{pp}$.

Lindström ER, Andr'en H, Angelstam P, Cederlund $G$, Hörnfeldt B, Jäderberg L, Lemnell PA, Martinsson B, Sköld, $K$, Swenson JE: Disease reveals the predator: sarcoptic mange, red fox predation, and prey populations. Ecology, 1994, 75, 10421049.

Mörner T, Christensson D: Experimental infection of red foxes (Vulpes vulpes) with Sarcoptes scabiei var. vulpes. Veterinary Parasitol. 1984, 15, 159164.

Plowright W: Research on wildlife diseases: is a reappraisal necessary? Rev. sci. tech. Off. int. Epiz. 1988, 7, 783-795.

Steinar M: (Request to hunters: livetrap and disinfect a red fox!) Opfordring til Jægerne fra DMU: Fang og vask en ræv! Jæger, 1993, 4, 32-33.

Storm GL, Andrews RD, Phillips RL, Bishop RA, Siniff $D B$, Tester JR: Morphology, reproduction, dispersal, and mortality of Midwestern red fox populations. Wildlife Monographs, 1976, 49, 82 pp.

Todd AW, Gunson JR, Samuel WM: Sarcoptic mange: an important disease of coyotes and wolves of Alberta, Canada. In Proc. First Worldwide Furbearer Conf., J.A. Chapman and D. Pursley (eds.). 1981, 706-729.

Weber D: Zur Baubenutzung und ihrer Funktion beim Fuchs (Vulpes vulpes). Z. Saugtierk. 1985, 50, 356-368.

(Received November 20, 1993; accepted September 24, 1994).

Reprints may be requested from: K. Overskaug, Norwegian Institute for Nature Research, Tungesletta 2, N-7005 Trondheim, Norway. 